\title{
Flavonoids and Terpenoids Present in Sarcotestae of Ginkgo biloba and Their Seasonal Changes
}

\author{
Yasushi Endo*1, Junko HAYASHI*1, Kenshiro FuJimoto*1, \\ Haruo ShIBATA*2, Toshiya ONO*2, and Satoshi MOHRI ${ }^{* 3}$ \\ *1 Graduate School of Agricultural Science, Tohoku University \\ (1-1 Tsutsumidori-Amamiyamachi, Aoba-ku, Sendai-shi 981-8555) \\ *2 Toshin Seiko Co., Ltd. \\ (42-2 Shinmei, Ohkuma-Tazawa, Watari-gun, Miyagi-ken 989-2383) \\ *3 Industrial Technology Institute, Miyagi Prefectural Government \\ (2-2 Akedori, Izumi-ku, Sendai-shi 981-3206)
}

\begin{abstract}
In order to utilize sarcotestae of Ginkgo biloba for medical purposes, their flavonoids and terpenoids were qualitatively and quantitatively analyzed. Flavonols such as kaempferol, quercetin and isorhamnetin present in leaves could not be detected in sarcotestae while anthocyanidins of delphinidin and cyanidin were found. Sarcotestae were noted to contain small amounts of ginkgolides A, B and C as terpenoids, as did also the leaves. The composition of ginkgolides in sarcotestae were varied during maturation whereas quantity of anthocyanidins was independent on harvest season.
\end{abstract}

Key words : ginkgo biloba, flavonoid, terpenoid, anthocyanidin, ginkgolide

\section{Introduction}

Since leaf extracts from Ginkgo biloba have specific physiological functions such as antitumor activity, antioxidant and neurotropic function etc., they are available as medicine and functional foods $^{1,2)}$. The Ginkgo biloba extracts are a complex mixture of flavonoids and several other natural products such as terpenoids, steroids and organic acids. In particular, flavonoids and terpenoids are major classes which contribute to pharmacological and therapeutic actions. Nuts of Gingko biloba are also used as food and medicine so that their nutritional and antinutritional components have been investigated ${ }^{3}$. However, chemical compositions except for alkyl phenols (e.g. anacardic acids) which cause contact dermatitis ${ }^{4}$ and inhibit some dehydrogenase activities ${ }^{5,6)}$, especially flavonoids and terpenoids which seem to be contained in sarcotestae of Ginkgo biloba have not been studied yet since they are usually abolished after harvesting nuts.

Corresponding author: Yasushi ENDO
In this study, flavonoids and terpenoids were qualitatively and quantitatively analyzed for sarcotestae of Ginkgo biloba in order to utilize it as medical materials. Moreover, seasonal variation in flavonoids and terpenoids present in sarcotestae was also investigated.

\section{Experimental}

\section{$2 \cdot 1$ Materials}

Sarcotestae of Ginkgo biloba (variety : Kyuji) were harvested in Sobue-cho, Aichi, once a month from August to November, 1997, and then they were stored at $-30^{\circ} \mathrm{C}$ until analysis.

Cyanidin, delphinidin, kaempferol, quercetin, and isorhamnetin were purchased as standard flavonoids (HPLC grade) from Extrasynthese S.A. Ginkgolides A, B, and C, and bilobalide were purchased as standard terpenoids (HPLC grade) from Sigma Chemical Co.

\section{$\mathbf{2} \cdot 2$ Analytical Methods}

Flavonoids were extracted as aglycons by refluxing $1 \mathrm{~g}$ of each freeze-dried sarcotestae with $20 \mathrm{ml}$ of $3 \% \mathrm{HCl}$-methanol solution for $1 \mathrm{~h}^{7}$. The mixture was filtrated with a glass filter and then 
concentrated by a rotary evaporator. The concentrates were prepared in $25 \mathrm{ml}$ of $0.01 \% \mathrm{HCl}$ methanol solution. Flavonoid aglycons were qualified by TLC and HPLC. For the TLC analysis ${ }^{7}$, a HPTLC cellulose plate and phenol/ water $(73: 27$, vol) as mobile phase were used. Flavonoid aglycons were detected by spraying $1 \%$ $\mathrm{AlCl}_{3}$-ethanol solution. For the HPLC analysis ${ }^{8}$, two Shodex ODSpak F-511 columns $(4.6 \times 250$ $\mathrm{mm}$, Shoko Co. Ltd., Tokyo) were used and kept at $40^{\circ} \mathrm{C}$. The mobile phase was a mixture of aqueous $10 \%$ acetic acid and acetonitrile (85:15, vol) and the flow rate was $0.8 \mathrm{~mL} / \mathrm{min}$. Flavonoid aglycons, viz. anthocyanidins, were monitored with a photodiode array detector and determined from the peak area at $530 \mathrm{~nm}$ using the calibration curve of standard anthocyanidins.

Terpenoids were extracted according to the method of Tallevi and Kurz". Briefly, $4 \mathrm{~g}$ of freeze-dried sarcotestae in $80 \mathrm{ml}$ water were boiled for $20 \mathrm{~min}$, followed by filtration through Whatman No.1 paper and celite (Hyflo Supercel). Activated charcol was added to the filtrate and allowed to stir for $12 \mathrm{~h}$ at room temperature. After the mixture was centrifuged, the residual charcol resuspended in acetone and then purified with Waters Sep-Pak Plus $\mathrm{NH}_{2}$ cartridge column jointed with Sep-Pak Plus C 18 cartridge column according to the method of Van Beek et al. ${ }^{10)}$ prior to HPLC analysis. An Inertsil ODS-2 column (4.6 $\times 250 \mathrm{~mm}$, GL Science Inc., Tokyo) was used as a HPLC column and was kept at $50^{\circ} \mathrm{C}$. The mobile phase was a mixture of water and methanol $(67: 33$, vol) and the flow rate was $0.8 \mathrm{~mL} / \mathrm{min}$. Terpenoids were monitored with a photodiode array detector and determined from the peak area at $220 \mathrm{~nm}$ using the calibration curve of standard terpenoids.

\section{Results and Discussion}

It is well known that leaves of Ginkgo biloba contain flavonoids, mainly flavonols at level of 0.4 $\sim 0.7 \mathrm{w} \%^{11}$. Major flavonols are kaempferol, quercetin and isorhamnetin. However, no flavonols were found in tested sarcotestae on the TLC plate. In the spectrophotometric analysis, $\mathrm{HCl}$ methanol extracts from sarcotestae had an absorption maximum at $530 \mathrm{~nm}$. This observation suggested the presence of anthocyanin (or anthocyanidin) in sarcotestas. Thus, anthocyanidins, aglycons of anthocyanins, were qualified by HPLC equipped with a photodiode array detector. Two major peaks were detected at retention time (Rt.) of $11.8 \mathrm{~min}$ and $15.7 \mathrm{~min}$ on the HPLC chromatogram at $530 \mathrm{~nm}$. The compound eluted at Rt.11.8 min had an absorption maximum at 535 $\mathrm{nm}$ and its absorption spectrum was completely consistent with that of delphinidin (Fig.1). Moreover, it showed a molecular ion peak of 303 on ESI-MS. An another compound at Rt.15.7 min had an absorption maximum at $527 \mathrm{~nm}$ and its absorption spectrum was the same as that of cyanidin (Fig.1). It showed a molecular ion peak of 287 on ESI-MS. Delphinidin and cyanidin were quantified by their area on the HPLC chromato-<smiles></smiles><smiles></smiles>

Cyanidin

Fig.1 Structures of Anthocyanidins.

Table 1 Anthocyanidin Contents (mg/100 $\mathrm{g}$ freeze-dried) in Sarcotestae of Ginkgo biloba.

\begin{tabular}{lccc}
\hline & Delphinidin & Cyanidin & Total \\
\hline August & $54.5 \pm 2.7$ & $32.4 \pm 1.6$ & $86.9 \pm 3.5$ \\
September & $39.4 \pm 1.2$ & $18.7 \pm 0.6$ & $58.1 \pm 1.6$ \\
October & $50.4 \pm 1.5$ & $28.1 \pm 0.8$ & $78.5 \pm 2.4$ \\
November & $46.6 \pm 1.4$ & $24.8 \pm 0.7$ & $71.4 \pm 1.4$ \\
\hline
\end{tabular}

Data means average \pm standard deviation $(n=5)$ 
gram at $530 \mathrm{~nm}$. As shown in Table 1, total amounts of delphinidin and cyanidin were ranged from 58 to $87 \mathrm{mg} / 100 \mathrm{~g}$ (dry basis) in sarcotestae and they were almost similar to those in fruits such as cranberry and red rasberry. The ratio of delphinidin and cyanidin was almost 2:1 and was not affected by harvest season. On the other hand, these anthocyanidins were not found in leaf extracts of Ginkgo biloba.

Terpenoids extracted from four sarcotestae were supplied to HPLC analysis. Three major terpenoids corresponding to ginkgolides A, B and C (Fig.2) which could act as antagonists of platelet activating factors $^{1) .2)}$ were found at Rt.18.2, 20.2 and $14.9 \mathrm{~min}$, respectively, on the HPLC chromatogram at $220 \mathrm{~nm}$. Their UV spectra and retention time were consistent with those of standard ginkgolides. Moreover, these ginkgolides $\mathrm{A}, \mathrm{B}$, and $\mathrm{C}$ were colored blue (Rf.0.52), yellow $(0.47)$, and pale orange $(0.28)$, respectively by UV-irradiation on a TLC plate developed with ethyl acetate/toluene/acetone/hexane (40:30:20: 10 , vol). On the other hand, bilobalide, major terpenpoids contained in leaves, and ginkgolide $\mathrm{J}$

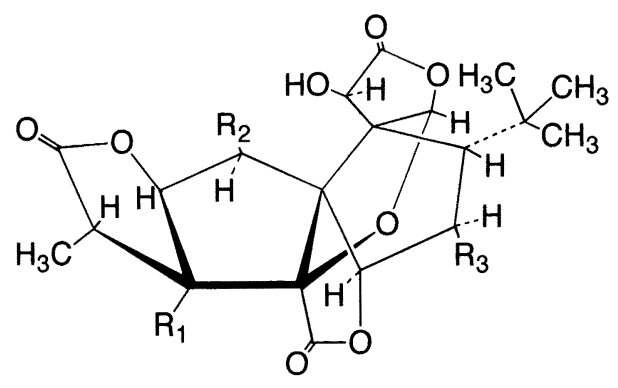

Ginkgolide $\mathrm{A}: \mathrm{R} 1=\mathrm{OH}, \mathrm{R} 2=\mathrm{R} 3=\mathrm{H}$

Ginkgolide $\mathrm{B}: \mathrm{R} 1=\mathrm{R} 2=\mathrm{OH}, \mathrm{R} 3=\mathrm{H}$

Ginkgolide $\mathrm{C}: \mathrm{R} 1=\mathrm{R} 2=\mathrm{R} 3=\mathrm{OH}$

Fig.2 Structures of Terpenoids. were not found in any tested sarcotestae on HPLC and TLC analyses. Ginkgolides A, B, and C were quantified by their area on the HPLC chromatogram at $220 \mathrm{~nm}$. Table 2 shows amounts of terpenoids in four sarcotestae. They were varied by harvest season. Immature sarcotestae harvested on August and September contained $12 \mathrm{mg} / 100 \mathrm{~g}$ of ginkgolides while mature ones on October and November contained higher amounts of ginkgolides $(27 \mathrm{mg} / 100 \mathrm{~g})$. Total amounts of terpenoids in sarcotestae were higher than those in nuts (1.5 $\mathrm{mg} / 100 \mathrm{~g}$ ) but were $1 / 10$ of those in leaves. Moreover, the composition of ginkgolides in sarcotestae depended on harvest season. Only ginkgolides A and B were present in an immature sarcotesta harvested on August although ginkgolide $\mathrm{C}$ was also found in ones on September, October and November as well as ginkgolides $\mathrm{A}$ and B. Amounts of ginkgolide $\mathrm{A}$ were not varied during maturation. Ginkgolide B was increased until October but decreased on November while ginkgolide $\mathrm{C}$ increased with maturation. These observations suggest that ginkgolide $\mathrm{C}$ may be synthesized from ginkgolide $B$.

Flavonoids and terpenoids were analyzed for sarcotestae of Ginkgo biloba. As a result, flavonoids present in sarcotestae are quite different from those in leaves. Considerable amounts of anthocyanidins were contained in sarcotestae although flavonols were not found in them. We found trace amounts of tocopherols and carotenoids in sarcotestae (data not shown). Thus, these anthocyanidins may protect sarcotesta cells from oxidative damage as natural antioxidants instead of tocopherols and flavonols. Amounts and compositions of terpenoids present in sarcotestae are also different from those in leaves and nuts. Unfortunately, sarcotestae could not substitute with leaves as of sources of flavonols and terpenoids. However, anthocyanins extracted

Table 2 Terpenoid Contents (mg/100 $\mathrm{g}$ freeze-dried) in Sarcotestae of Ginkgo biloba.

\begin{tabular}{lrrrr}
\hline & Ginkgolide A & Ginkgolide B & Ginkgolide C & Total \\
\hline August & $7.7 \pm 0.2$ & $4.0 \pm 0.1$ & 0 & $11.7 \pm 0.3$ \\
September & $7.6 \pm 0.2$ & $4.4 \pm 0.1$ & $1.0 \pm 0.1$ & $12.7 \pm 0.3$ \\
October & $10.6 \pm 0.3$ & $11.4 \pm 0.3$ & $5.3 \pm 0.2$ & $27.3 \pm 0.6$ \\
November & $10.0 \pm 0.3$ & $6.1 \pm 0.2$ & $11.3 \pm 0.3$ & $27.4 \pm 0.6$ \\
\hline
\end{tabular}

Data means average \pm standard deviation $(n=5)$ 
from sarcotestae might be available as medical materials and coloring agents.

(Received Feb.8, 1999 ; Accepted Apr. 12, 1999)

\section{References}

1) F.V. DeFeudis, "Ginkgo biloba Extract (Edb 761): Pharmacological Activities and Clinical Applications", Elsevier, Paris (1991).

2) Y. Christen, J. Costentin, M. Lacour, "Effects of Ginkgo biloba Extract (Egb 761) on the Central Nervous System", Elsevier, Paris (1992).

3) M. Ogushi, E. Yanazawa, A. Yoshikawa, R. Harada, J. Jpn. Soc. Nutr. Food Sci. (In Japanese), 42, 245 (1989).

4) F. Saito, Hihu (In Japanese), 30, (1988).

5) J. Irie, M. Murata, S. Homma, Biosci. Biotech.
Biochem., 60, 240 (1996).

6) M. Murata, J. Irie, S. Homma, Lebensm.-Wiss. u.Technol., 30, 458 (1997).

7) T. Nakabayashi, "Chemistry of Color Change in Food" ed. S. Kimura, T. Nakabayashi, H. Kato, Kohrin, Tokyo, (1995) p.1.

8) V. Hong, R.E. Wrolstad, J. Agric. Food Chem., 38, 708 (1990).

9) S.G. Tellevi, W.G.W. Kurz, J. Natural Products, 54, 624 (1991).

10) T.A. Van Beek, H.A. Scheeren, T. Rantio, W. Ch. Melger, G.P. Lelyveld, J. Chromatogr., 543, 375 (1991).

11) A. Hasler, O. Sticher, B. Meier, J. Chromatogr., 605, 41 (1992). 


\section{[報文］Ｎ-ラウロイルグルタミン酸塩の中和 による性質の変化}

金子 大介・服部 達也・坂本 一民

味の素株式会社アミノサイエンス研究所（干210-8681 神奈川県川崎市川崎区鈴木町 1-1）

$N$-ラウロイルグルタミン酸塩の中和の度合いによる性質の変化を調べた。起泡力は中和度が 1.6 で極大を示 し，乳化力は中和度に伴い減少した。 ${ }^{13} \mathrm{C}-\mathrm{NMR}$ の結果より， $\alpha$ 位のカルボン酸から優先的に中和され，引き続 き $\gamma$ 位のカルボン酸が中和度 1.6 以降で中和されることがわかった。さらに蛍光プローブ法から, 中和度 1.6 付近 でミセルの微視的極性および会合数が急激に増加することがわかった。これらの結果から， $\alpha$ 位の力ルボン酸が分 子間の相互作用に寄与していることが示唆された。

（連絡者：金子大介）Vol. 48, No. 7, 713(1999)

\section{[ノート］イチョウ果皮に存在するフラボノイドと テルペノイドおよびその季節変動}

\section{遠藤 泰志*1 ・林順子*1 ・藤本健四郎 ${ }^{* 1}$ 柴田 晴雄 ${ }^{* 2}$}

小野 利也 ${ }^{* 2} \cdot$ 毛利哲*3

$* 1$ 東北大学大学院農学研究科（干981-8555 仙台市青葉区堤通雨宮町 1-1)

$* 2$ (株)東伸精工（广989-2383 宮城県亘理郡亘理町逢隈田沢字神明 42-2)

*3 宮城県産業技術総合センター（T981-3206 仙台市泉区明通 2-2）

廃棄物であるイチョウ果皮を医薬品として有効利用するため，イチョウ果皮に含まれるフラボノイドとテルペノ イドの定性・定量分析を行った。イチョウの葉に存在するケンフェロールやケルセチン，イソラムネチンのような フラボノールは果皮では検出されなかったが, デルフィニジンやシアニジンのアントシアニジンが存在していた。 また果皮には，葉と同様にテルペノイドとしてギンコライドを少量含んでいた。果皮のアントシアニジン量は収穫 時期に依存しなかったが，ギンコライドの組成は成熟中に変化した。

（連絡者：遠藤泰志）Vol. 48, No. 7, 719 (1999) 